\title{
The Substrate Specificity of the Enzyme Amyloglucosidase (AMG). Part I. Deoxy Derivatives
}

\author{
Klaus Bock and Henrik Pedersen \\ Department of Organic Chemistry, The Technical University of Denmark, Building 201, DK-2800 Lyngby, \\ Denmark
}

\begin{abstract}
Bock, K. and Pedersen, H., 1987. The Substrate Specificity of the Enzyme Amyloglucosidase (AMG). Part I. Deoxy Derivatives. - Acta Chem. Scand., Ser. B 41: 617-628.

The eight possible monodeoxy derivatives of methyl $\beta$-maltoside and two bisdeoxy derivatives have been synthesized. The unprotected glycosides have all been investigated by NMR $\left({ }^{1} \mathrm{H}\right.$ and ${ }^{13} \mathrm{C}$ ) spectroscopy in order to confirm their structures and to obtain supporting information about their preferred solution conformations. The compounds have all been tested as substrates toward the hydrolase, amyloglucosidase (AMG) and it has been demonstrated that three hydroxy groups $\left(3,4^{\prime}\right.$ and $\left.6^{\prime}\right)$ are essential for the compounds to act as substrate for the enzyme. The kinetic parameters $K_{\mathrm{M}}$ (Michaelis-Menten constant) and $V_{\mathrm{M}}$ (maximum rate for the reaction) have been determined using ${ }^{1} \mathrm{H}$ NMR spectroscopy at $500 \mathrm{MHz}$.
\end{abstract}

The recognition of complex oligosaccharides by antibodies has been studied extensively by Lemieux and his coworkers. ${ }^{1-4}$ This work has demonstrated that specific hydroxy groups are required for the binding of the carbohydrates by the protein, whereas other hydroxy groups do not play a major role in the recognition process but merely contribute to the overall strength of the binding to the protein.

In order to investigate this proposal in a model system where oligosaccharides are cleaved by hydrolytic enzymes we have synthesized a series of monodeoxy derivatives of methyl $\beta$-maltoside. Preliminary reports of this work have appeared previously. ${ }^{5-6}$ The synthetic compounds have been investigated with respect to their substrate activity towards the enzyme amyloglocusidase [AMG (EC.3.2.1.3)]. This enzyme is produced technically in very large amounts and plays an important role in the processing of starch. The amino acid sequence of the enzyme has been determined by Svensson et al., ${ }^{7}$ but it has not been possible to crystallize it in order to obtain a detailed picture of the active site and the mechanism by which the enzyme functions when it hydrolyses maltose and higher oligomers to glucose.
Here we wish to report on the synthesis of all the mono- and two bisdeoxy derivatives of maltose and an investigation of whether these compounds are substrates for the enzyme AMG.

\section{Results and discussion}

The peracetates of the monodeoxy derivatives methyl 6-deoxy- $\beta$-maltoside (1b), methyl 6'-deoxy- $\beta$-maltoside (2b) and 4-O- $\alpha$-D-glucopyranosyl-1,5-anhydro-D-glucitol (3b) have all been synthesized previously. ${ }^{8-10}$ The unprotected compounds 1a, 2a and 3a were prepared according to the published procedures, followed by deacetylation and characterization by ${ }^{1} \mathrm{H}$ and ${ }^{13} \mathrm{C}$ NMR spectroscopy (Tables 1 and 2).

The 3-deoxy derivative 5a was prepared by tinhydride reduction of the 3-chloro-3-deoxy allocompound $(4)^{11}$ and isolated in high yield (75\%) as the 3-deoxy peracetate (5b). Deacetylation with sodium methoxide in methanol afforded 5a in $73 \%$ yield after purification by chromatography on a Sephadex G-15 column.

The 2 '-deoxy compound was prepared by glycoside synthesis using methyl 2,3,6-tri- $O$-benzyl$\beta$-D-glucopyranoside $(6)^{12}$ as the aglycone and tri- 
BOCK AND PEDERSEN

Table 1. ' $\mathrm{H}$ NMR spectral data for compounds $1-16$ in $\mathrm{D}_{2} \mathrm{O}^{a}$.

\begin{tabular}{|c|c|c|c|c|c|c|c|c|}
\hline Compound & $\mathrm{H}-1$ & $\mathrm{H}-2$ & $\mathrm{H}-3$ & $\mathrm{H}-4$ & $\mathrm{H}-5$ & $\mathrm{H}-6$ & $H-6^{\prime}$ & $\mathrm{OMe}$ \\
\hline 1a a-unit & $\begin{array}{l}5.34 \\
3.8\end{array}$ & $\begin{array}{l}3.55 \\
9.2\end{array}$ & 3.62 & 3.35 & 3.71 & 3.71 & 3.80 & \\
\hline 1a b-unit & $\begin{array}{l}4.30 \\
8.5\end{array}$ & $\begin{array}{l}3.23 \\
9.2\end{array}$ & 3.66 & 3.33 & $\begin{array}{l}3.57 \\
6.3\end{array}$ & 1.34 & & 3.49 \\
\hline 2a a-unit & $\begin{array}{l}5.32 \\
3.5\end{array}$ & 3.59 & $\begin{array}{l}3.62 \\
9.0\end{array}$ & $\begin{array}{l}3.16 \\
9.0\end{array}$ & $\begin{array}{l}3.78 \\
6.3\end{array}$ & 1.27 & & \\
\hline $2 a$ b-unit & $\begin{array}{l}4.39 \\
8.0\end{array}$ & $\begin{array}{l}3.29 \\
9,2\end{array}$ & 3.75 & 3.58 & 3.55 & $\begin{array}{l}3.90 \\
5.0\end{array}$ & $\begin{array}{l}3.72 \\
5.1,12.0\end{array}$ & 3.55 \\
\hline 5a a-unit & $\begin{array}{l}5.10 \\
3.8\end{array}$ & $\begin{array}{l}3.56 \\
9.5\end{array}$ & 3.61 & 3.42 & $3.62^{b}$ & $\begin{array}{l}3.84 \\
2.5\end{array}$ & $\begin{array}{l}3.76 \\
5.1,12.0\end{array}$ & \\
\hline $5 \mathrm{a}$ b-unit & $\begin{array}{l}4.38 \\
7.5\end{array}$ & $\begin{array}{l}3,46 \\
2.59 \mathrm{eq} \\
5.0,12.0\end{array}$ & $\begin{array}{l}1.49 \mathrm{az} \\
12.0\end{array}$ & 3.71 & $3.61^{b}$ & $\begin{array}{l}3.96 \\
2.5\end{array}$ & $\begin{array}{l}3.70 \\
6.0 .12 .0\end{array}$ & 3.56 \\
\hline 9a a-unit & $\begin{array}{l}5.45 \\
3.8\end{array}$ & $\begin{array}{c}1.70 \mathrm{ax} \\
13.0,4.0 \\
2.21 \mathrm{eq} \\
13.1\end{array}$ & $\begin{array}{c}3.84 \\
12.0 \\
\\
5.0\end{array}$ & $\begin{array}{c}3.34 \\
10.0\end{array}$ & 3.62 & $\begin{array}{l}3.82 \\
2.5\end{array}$ & $\begin{array}{l}3.74 \\
5.0,12.0\end{array}$ & \\
\hline $9 a$ b-unit & $\begin{array}{l}4.33 \\
8.0\end{array}$ & $\begin{array}{l}3.24 \\
9.5\end{array}$ & 3.61 & 3.56 & 3.49 & $\begin{array}{l}3.88 \\
2.0\end{array}$ & $\begin{array}{l}3.70 \\
5.5,12.1\end{array}$ & 3.53 \\
\hline 11a a-unit & $\begin{array}{l}5.23 \\
3.8\end{array}$ & $\begin{array}{l}3.77 \\
2.12 \mathrm{eq} \\
4.5,11.5\end{array}$ & $\begin{array}{l}1.69 \mathrm{ax} \\
11.5\end{array}$ & 3.55 & & $\begin{array}{l}3.79 \\
1.5\end{array}$ & $\begin{array}{l}3.66 \\
5.5,12.5\end{array}$ & \\
\hline 11b b-unit & $\begin{array}{l}4.34 \\
8.0\end{array}$ & $\begin{array}{l}3.25 \\
9.5\end{array}$ & $\begin{array}{c}3.71 \\
10.0\end{array}$ & 3.59 & 3.54 & $\begin{array}{l}3.92 \\
1.5\end{array}$ & $\begin{array}{l}3.75 \\
5.0,12.5\end{array}$ & 3.53 \\
\hline $14 a$ a-unit & $\begin{array}{l}5.35 \\
3.8\end{array}$ & $\begin{array}{c}3.47 \\
10.0\end{array}$ & 3.73 & $\begin{array}{l}1.90 \mathrm{ax} \\
12.0 \\
2.55 \mathrm{eq} \\
2.0,5.0,12.0\end{array}$ & 3.97 & $\begin{array}{l}3.88 \\
5.0\end{array}$ & $\begin{array}{l}3.90 \\
5.0,12.0\end{array}$ & \\
\hline 14 b-unit & $\begin{array}{l}4.35 \\
8.0\end{array}$ & $\begin{array}{l}3.26 \\
9.5\end{array}$ & 3.72 & 3.55 & 3.54 & $\begin{array}{l}3.91 \\
2.0\end{array}$ & $\begin{array}{l}3.63 \\
5.0,12.0\end{array}$ & 3.53 \\
\hline 15a a-unit & $\begin{array}{l}5.27 \\
3.5\end{array}$ & 3.57 & $\begin{array}{l}3.57 \\
9.0\end{array}$ & $\begin{array}{l}3.13 \\
9.0\end{array}$ & $\begin{array}{l}3.59 \\
6.3\end{array}$ & 1.26 & & \\
\hline 15a b-unit & $\begin{array}{l}4.32 \\
8.0\end{array}$ & $\begin{array}{l}3.25 \\
9.5\end{array}$ & $\begin{array}{l}3.66 \\
9.5\end{array}$ & $\begin{array}{l}3.28 \\
9.5\end{array}$ & $\begin{array}{l}3.80 \\
6.3\end{array}$ & 1.32 & & 3.52 \\
\hline 16a a-unit & $\begin{array}{c}3.50 \mathrm{ax} \\
12.4,12.4 \\
3.95 \mathrm{eq} \\
5.2,1.9\end{array}$ & $\begin{array}{l}1.64 \mathrm{ax} \\
12.5 \\
1.98 \mathrm{eq} \\
1.7\end{array}$ & $\begin{array}{l}3.90 \\
9.0\end{array}$ & $\begin{array}{l}3.46 \\
9.0\end{array}$ & 3.38 & $\begin{array}{l}3.83 \\
2.2\end{array}$ & $\begin{array}{l}3.70 \\
5.5,12.1\end{array}$ & \\
\hline $16 a$ b-unit & $\begin{array}{l}5.34 \\
3.9\end{array}$ & $\begin{array}{l}3.57 \\
9.5\end{array}$ & $\begin{array}{l}3.67 \\
9.5\end{array}$ & $\begin{array}{l}3.39 \\
9.5\end{array}$ & 3.7 & $\begin{array}{l}3.87 \\
2.2,12.1\end{array}$ & 3.7 & \\
\hline
\end{tabular}

${ }^{a}$ Measured at $500 \mathrm{MHz}$ in $\mathrm{D}_{2} \mathrm{O}$ at $300 \mathrm{~K}$, in ppm relative to $\mathrm{DOH}=4.75 \mathrm{ppm}$. Observed first-order coupling constants given below the chemical shifts. ${ }^{b}$ Assignments may be reversed. 
Table 2. ${ }^{13} \mathrm{C}$ NMR spectral data for compounds 1-16 in $\mathrm{D}_{2} \mathrm{O}^{\text {a }}$.

\begin{tabular}{|c|c|c|c|c|c|c|c|}
\hline Compound & $\mathrm{C}-1$ & $\mathrm{C}-2$ & $\mathrm{C}-3$ & $C-4$ & $\mathrm{C}-5$ & C-6 & OMe \\
\hline $\begin{array}{l}1 \text { a a-unit } \\
\text { 1a b-unit }\end{array}$ & $\begin{array}{l}100.5 \\
104.1\end{array}$ & $\begin{array}{l}72.7 \\
74.3\end{array}$ & $\begin{array}{l}73.9 \\
77.2\end{array}$ & $\begin{array}{l}70.5 \\
83.1\end{array}$ & $\begin{array}{l}73.6 \\
71.6\end{array}$ & $\begin{array}{l}61.6 \\
18.4\end{array}$ & 58.2 \\
\hline $\begin{array}{l}2 a \text { a-unit } \\
2 a \text { b-unit }\end{array}$ & $\begin{array}{l}100.9 \\
103.9\end{array}$ & $\begin{array}{l}72.7 \\
73.9\end{array}$ & $\begin{array}{l}73.4 \\
77.0\end{array}$ & $\begin{array}{l}75.6 \\
77.8\end{array}$ & $\begin{array}{l}69.4 \\
75.3\end{array}$ & $\begin{array}{l}17.3 \\
61.6\end{array}$ & 58.0 \\
\hline $\begin{array}{l}\text { 3a a-unit } \\
\text { 3a b-unit }\end{array}$ & $\begin{array}{r}69.8 \\
100.7\end{array}$ & $\begin{array}{l}70.3 \\
72.7\end{array}$ & $\begin{array}{l}78.2 \\
73.9\end{array}$ & $\begin{array}{l}78.9 \\
69.6\end{array}$ & $\begin{array}{l}79.7 \\
69.6\end{array}$ & $\begin{array}{l}61.5 \\
61.9\end{array}$ & \\
\hline $\begin{array}{l}\text { 5a a-unit } \\
\text { 5a b-unit }\end{array}$ & $\begin{array}{r}95.7 \\
106.5\end{array}$ & $\begin{array}{l}72.1 \\
68.8\end{array}$ & $\begin{array}{l}73.7 \\
35.2\end{array}$ & $\begin{array}{l}70.6 \\
69.0\end{array}$ & $\begin{array}{l}74.1 \\
79.1\end{array}$ & $\begin{array}{l}61.6 \\
62.1\end{array}$ & 58.2 \\
\hline $\begin{array}{l}\text { 9a a-unit } \\
\text { 9a b-unit }\end{array}$ & $\begin{array}{r}99.6 \\
104.1\end{array}$ & $\begin{array}{l}37.9 \\
74.2\end{array}$ & $\begin{array}{l}68.9 \\
76.2\end{array}$ & $\begin{array}{l}71.8 \\
77.5\end{array}$ & $\begin{array}{l}74.3 \\
75.6\end{array}$ & $\begin{array}{l}61.8 \\
61.6\end{array}$ & 58.1 \\
\hline $\begin{array}{l}11 a \text { a-unit } \\
11 a \text { b-unit }\end{array}$ & $\begin{array}{r}99.2 \\
104.1\end{array}$ & $\begin{array}{l}67.7 \\
74.0\end{array}$ & $\begin{array}{l}35.2 \\
77.3\end{array}$ & $\begin{array}{l}65.0 \\
77.6\end{array}$ & $\begin{array}{l}74.5 \\
75.7\end{array}$ & $\begin{array}{l}61.8^{b} \\
61.6^{b}\end{array}$ & 58.1 \\
\hline $\begin{array}{l}14 a \text { a-unit } \\
14 a \text { b-unit }\end{array}$ & $\begin{array}{l}101.3 \\
103.9\end{array}$ & $\begin{array}{l}74.3 \\
73.8\end{array}$ & $\begin{array}{l}70.5^{b} \\
77.0\end{array}$ & $\begin{array}{l}34.7 \\
78.0\end{array}$ & $\begin{array}{l}67.9^{b} \\
75.3\end{array}$ & $\begin{array}{l}64.4 \\
61.6\end{array}$ & 57.9 \\
\hline $\begin{array}{l}15 a \text { a-unit } \\
15 a \text { b-unit }\end{array}$ & $\begin{array}{l}100.5 \\
103.8\end{array}$ & $\begin{array}{l}72.7 \\
74.0\end{array}$ & $\begin{array}{l}73.5 \\
76.9\end{array}$ & $\begin{array}{l}75.6 \\
83.4\end{array}$ & $\begin{array}{l}69.3 \\
71.4\end{array}$ & $\begin{array}{l}17.2 \\
18.0\end{array}$ & 58.0 \\
\hline $\begin{array}{l}\text { 16a a-unit } \\
16 a \text { b-unit }\end{array}$ & $\begin{array}{r}66.2 \\
101.0\end{array}$ & $\begin{array}{l}33.7 \\
70.0\end{array}$ & $\begin{array}{l}79.7 \\
69.4\end{array}$ & $\begin{array}{l}73.6 \\
67.9\end{array}$ & $\begin{array}{l}80.6 \\
68.3\end{array}$ & $\begin{array}{l}62.1 \\
61.4\end{array}$ & \\
\hline
\end{tabular}

a Measured at $125.7 \mathrm{MHz}$ in $\mathrm{D}_{2} \mathrm{O}$ at $300 \mathrm{~K}$. ${ }^{b}$ Assignments may be reversed.

$O$-acetyl-D-glucal (7) as the glycosylating reagent in an $\mathrm{N}$-iodosuccinimide-catalyzed reaction as described by Thiem. ${ }^{13}$ The yield of the $\alpha$-linked disaccharide (8) was $26 \%$. Removal of the iodine with $\mathrm{Pd} / \mathrm{C}$ in ethyl acetate and triethylamine to the deoxy compound gave mixtures of products. Reduction with tributyltin hydride gave the desired deoxy compound $9 \mathrm{~b}$, isolated in $62 \%$ yield after catalytic debenzylation and re-acetylation. $\mathrm{De}-\mathrm{O}$-acetylation gave the desired $2{ }^{\prime}$-deoxy compound $9 \mathrm{a}$ in $80 \%$ yield.

The 3'-deoxy derivative 11a was obtained through a glycoside synthesis using the same aglycone (6) as described above. The glycosylating reagent was 2,4,6-tri- $O$-benzyl- $\alpha$-D-glucopyranosyl chloride (10), prepared from the corresponding methyl 4,6-O-benzylidene-3-deoxy- $\alpha$-D-glucopyranoside. ${ }^{14}$ The $\alpha$-linked disaccharide $11 c$ was isolated in $38 \%$ yield together with the $\beta$ linked compound (38\%) using the halide-catalyzed glycosylation reaction conditions described by Lemieux. ${ }^{15}$ Catalytic hydrogenation of the $\alpha$ linked compound with $\mathrm{Pd} / \mathrm{C}$ in methanol and acetic acid gave the desired compound 11a in $88 \%$ yield. The product was characterized as its peracetate (11b).

The $4^{\prime}$-deoxy derivative was synthesized from methyl 4,6- $O$-benzylidene- $\beta$-maltoside, which was protected as the $2,3,6,2^{\prime}, 3^{\prime}$ penta- $O$-benzyl derivative (12) and then reductively opened using sodium cyanoborohydride, as described by Hultberg and Garegg, ${ }^{12}$ to give the methyl $2,3,6,2^{\prime}, 3^{\prime}, 6^{\prime}$-hexa- $O$-benzyl- $\beta$-maltoside (13a) in good yield. This compound was converted into the phenoxy thiocarbonate (13d) ${ }^{16}$ and the thioester was reductively removed using tinhydride to give the $4^{\prime}$-deoxy compound $14 \mathrm{c}$, isolated in $67 \%$ yield. The benzyl groups were finally removed catalytically and the unprotected $4^{\prime}$-deoxy compound 14a isolated in $94 \%$ yield as a syrup. The 6,6'-dideoxy compound $15 \mathrm{a}$ and the 4-O- $\alpha$-D-glucopyranosyl-2-deoxy-1,5-anhydro-Darabino-hexitol (16a) were synthesized as described $^{9,17}$ and de-protected to give the free sugars.

All unprotected compounds were characterized through their ${ }^{1} \mathrm{H}$ and ${ }^{13} \mathrm{C}$ NMR parameters determined at $500 \mathrm{MHz}$. The data are presented 
BOCK AND PEDERSEN

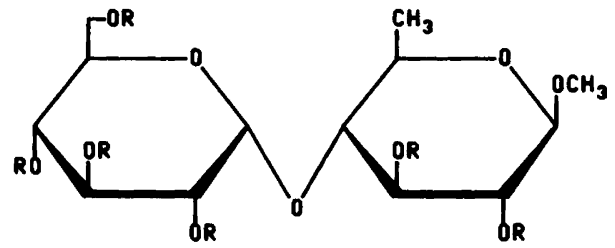

1

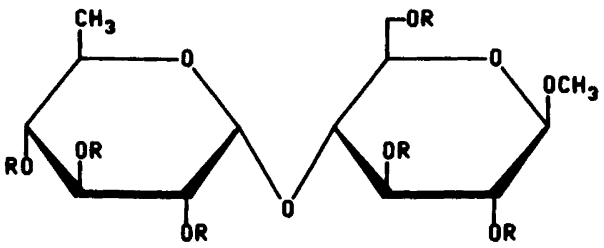

2

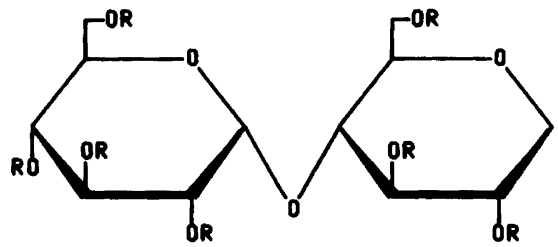

3

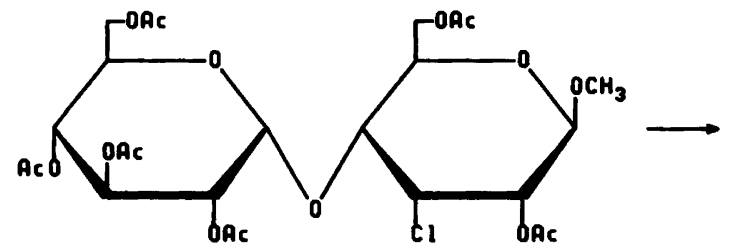

4

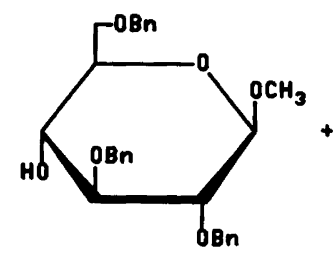

6

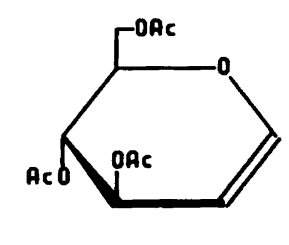

7

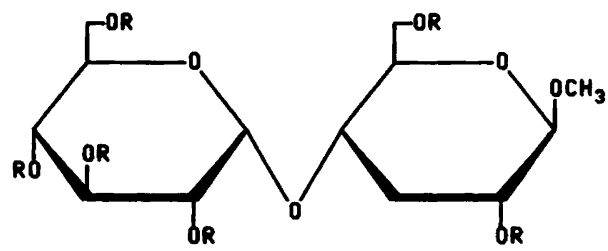

5

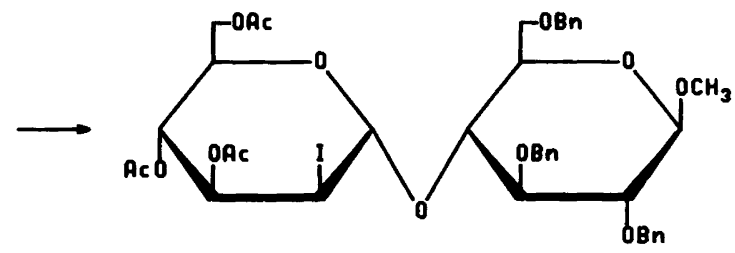

8

$a: R=H$
$b: R=A c$
$c: R=B n$

620

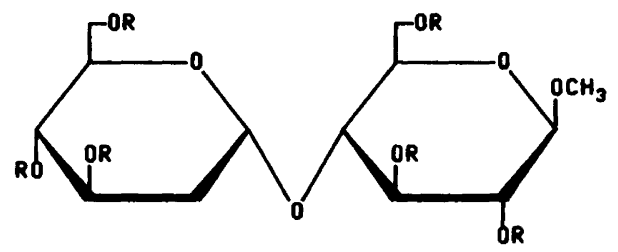

9 
DEOXY $\beta$-MALTOSIDE DERIVATIVES I

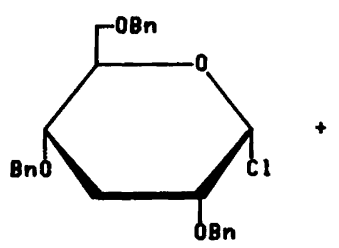

10

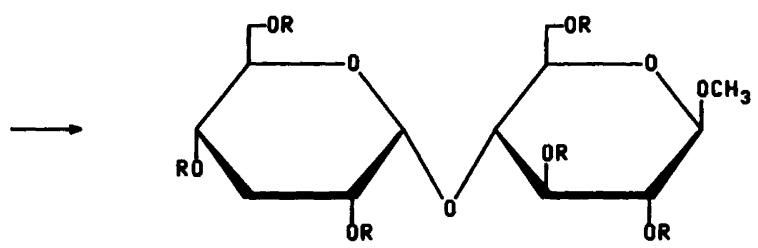

11

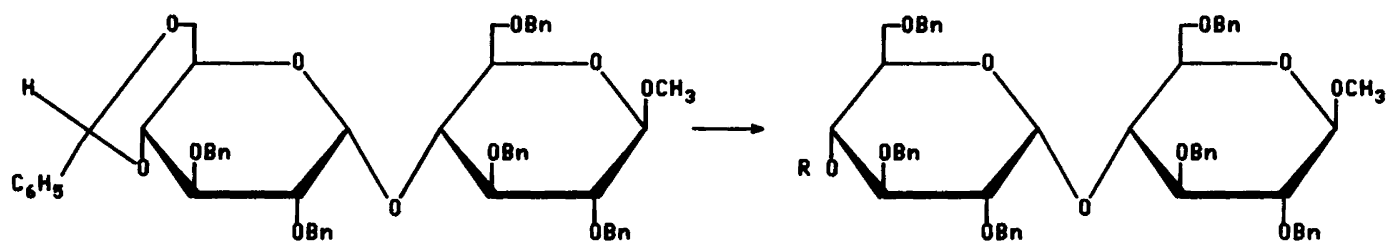

12

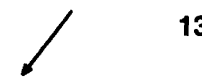

13

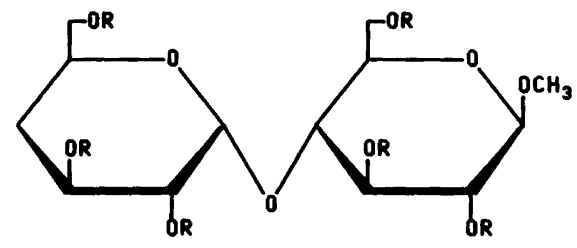

14

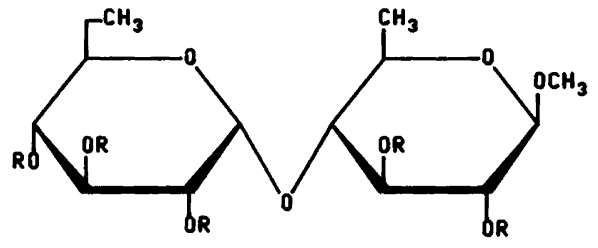

15

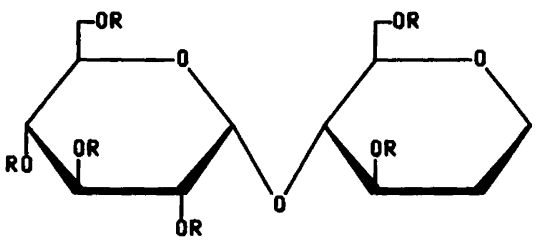

16

$$
\begin{aligned}
& a: R=H \\
& b: R=A C \\
& c: R=B n \\
& d: R=C_{6} H_{8} \text { OCS }
\end{aligned}
$$


Table 3. Substrate specificity of deoxy-maltose derivatives towards amyloglucosidase. ${ }^{a}$

\begin{tabular}{lll}
\hline Compound & Substrate & Not substrate \\
\hline $1 \mathbf{a}$ & + & \\
$2 \mathbf{a}$ & + & - \\
$3 \mathbf{a}$ & & - \\
$5 \mathbf{a}$ & + & \\
$9 \mathbf{a}$ & + & - \\
$11 \mathbf{a}$ & & $(-)^{b}$ \\
$14 \mathbf{a}$ & & \\
$15 \mathbf{a}$ & + & \\
$16 \mathbf{a}$ & & \\
\hline
\end{tabular}

${ }^{a}$ Qualitative experiments as described in the Experimental. ${ }^{b}$ The compound is a very poor substrate on prolonged exposure to AMG.

in Tables 1 and 2 and are in all cases in full agreement with the proposed structures.

The deoxy compounds described above were all tested qualitatively as potential substrates for the enzyme AMG in a $0.1 \mathrm{M}$ acetate buffer at $\mathrm{pH}$ 4.5 and $27^{\circ} \mathrm{C}$. The results presented in Table 3 clearly demonstrate that key-polar groups ${ }^{4}$ are important for the enzymatic activity since the 3-, $4^{\prime}$ and $6^{\prime}$-deoxy compounds were not substrates for the enzyme. All the other deoxy derivatives are hydrolyzed by the enzyme, however, at different rates relative to the reference compound methyl $\beta$-maltoside.

Four of the substrates, viz. 1a, 3a, 9a and 16a, were investigated in more detail using ${ }^{1} \mathrm{H}$ NMR spectroscopy and progress curve kinetics ${ }^{18}$ to determine the Michaelis-Menten constant $\left(K_{\mathrm{M}}\right)$ and maximum rate $\left(V_{\mathrm{M}}\right)$ of the reactions. These results were compared with data for methyl $\alpha$ - and $\beta$-maltoside (Table 4 ) and it is clearly seen that even though the deoxy derivatives are hydrolysed faster (smaller $V_{\mathrm{M}}$ ) than the corresponding hydroxy compounds, the $K_{2} / K_{\mathrm{M}}$ values are lower. This indicates ${ }^{18}$ that the binding of a deoxy derivative to the enzyme is weaker than that of the corresponding hydroxy compound, but that the transition states of the two reactions are of comparable energy; consequently, the hydrolysis of the deoxy compound is faster than that of the normal natural substrate, maltose.

\section{Conclusion}

The monodeoxy derivatives of maltose have been synthesized and fully characterized. It has been shown that the presence of each of three specific hydroxy groups $\left(3,4^{\prime}\right.$ and 6$)$ in maltose is essential for the compounds to act as substrate for the hydrolytic enzyme amyloglucosidase. On the other hand, removal of other hydroxy groups generally gives substrates which are hydrolysed faster than methyl maltoside, due to weaker association to the enzyme, but which have transition states of comparable energy.

\section{Experimental}

Melting points are uncorrected. Optical rotations were measured on a Perkin Elmer 241 polarimeter. NMR spectra were obtained on Bruker WH-90 and AM-500 NMR instruments. The spectra of protected compounds were measured in $\mathrm{CDCl}_{3}$, while those of unprotected compounds were measured in $\mathrm{D}_{2} \mathrm{O}$ relative to the internal references acetone $\left(\delta 2.22,{ }^{1} \mathrm{H}\right.$ NMR spectra) or dioxane (67.4 ppm, ${ }^{13} \mathrm{C}$ NMR spectra). Microanalyses were performed by Novo Microanalytical Laboratory, Copenhagen, Denmark. TLC was performed on silica gel-coated plates (Merck F-

Table 4. Kinetic parameters determined from dynamic NMR experiments. ${ }^{18}$

\begin{tabular}{|c|c|c|c|c|}
\hline Compound & $S_{0}{ }^{a} / \mu \mathrm{mol} \mathrm{ml} l^{-1}$ & $k_{\mathrm{M}} / \mu \mathrm{mol} \mathrm{ml^{-1 }}$ & $\mathrm{V}_{\mathrm{M}} / \mathrm{\mu mol} \mathrm{min}^{-1}$ & $K_{2} / K_{\mathrm{M}}{ }^{\mathrm{b}} / \mathrm{M} \mathrm{s}^{-1}$ \\
\hline Methyl $\beta$-maltoside & 5.98 & 0.33 & 0.13 & $9.7 \cdot 10^{3}$ \\
\hline Methyl $\beta$-maltoside & 31.2 & 0.52 & 0.30 & $1.4 \cdot 10^{4}$ \\
\hline 1 a & 7.23 & 0.36 & 0.14 & $9.0 \cdot 10^{3}$ \\
\hline $\mathbf{3 a}$ & 17.8 & 5.2 & 0.89 & $4.2 \cdot 10^{3}$ \\
\hline $9 a$ & 7.27 & 3.6 & 0.39 & $2.5 \cdot 10^{3}$ \\
\hline $16 \mathbf{a}$ & 22.3 & 9.1 & 0.47 & $1.2 \cdot 10^{3}$ \\
\hline
\end{tabular}

${ }^{a}$ Initial concentration. ${ }^{b}$ Constant enzyme amount in each experiment $50 \mu \mathrm{g}\left(\mathrm{MW}=71000 \mathrm{~g} \mathrm{~mol}^{-1}\right)$. 
254). Preparative TLC was performed on $20 \times 40$ $\mathrm{cm}$ plates coated with $1 \mathrm{~mm}$ of silica gel. The enzyme amyloglucosidase [AMG (EC. 3.2.1.3)] was a gift from Novo A/S, Denmark.

Methyl 2,3,6,2',3',4'-hexa-O-acetyl-6'-bromo$\sigma^{\prime}$-deoxy- $\beta$-maltoside. A mixture of methyl $2,3,6,2^{\prime}, 3^{\prime}$-penta- $O$-acetyl-4', $6^{\prime}$ - $O$-benzylidene$\beta$-maltoside ${ }^{19}(2.0 \mathrm{~g}, 3.06 \mathrm{mmol})$ and barium carbonate $(1 \mathrm{~g}, 5.08 \mathrm{mmol})$ in tetrachloromethane $(150 \mathrm{ml})$ was dried by distilling off tetrachloromethane $(75 \mathrm{ml}) . \quad N$-Bromosuccinimide (600 $\mathrm{mg}, 3.37 \mathrm{mmol}$ ) was added, and the mixture was heated under reflux with magnetic stirring for $30 \mathrm{~min}$. The mixture was filtered while still hot, and the filter cake was washed with dichloromethane $(50 \mathrm{ml})$. The combined filtrate and washings were washed twice with $10 \%$ sodium thiosulfate solution $(50 \mathrm{ml})$, three times with $4 \mathrm{M}$ hydrochloric acid $(50 \mathrm{ml})$, and three times with saturated sodium hydrogen carbonate solution $(50 \mathrm{ml})$. Drying of the organic phase over magnesium sulfate and evaporation to dryness yielded $2.10 \mathrm{~g}(2.86 \mathrm{mmol}, 94 \%)$. The $90 \mathrm{MHz}{ }^{1} \mathrm{H}$ NMR spectrum showed two complex spin systems at $7.47 \mathrm{ppm}$ and $7.98 \mathrm{ppm}$ (4'-O-benzoyl). The $6^{\prime}$-bromide $(2.10 \mathrm{~g}, 2.86$ mmol) was treated with $0.1 \%$ sodium methoxide in methanol $(25 \mathrm{ml})$ for $16 \mathrm{~h}$. Solid carbon dioxide $(2 \mathrm{~g})$ was added, and the mixture was evaporated. Water $(10 \mathrm{ml})$ was added and evaporated three times to remove methyl benzoate. Toluene $(10 \mathrm{ml})$ was then added and evaporated twice to remove water, and the residue was treated with acetic anhydride $(10 \mathrm{ml})$ and pyridine $(10 \mathrm{ml})$ for $4 \mathrm{~h}$. Work-up in the conventional manner gave a syrup $(1.80 \mathrm{~g})$, from which the title compound (830 $\mathrm{mg}, 1.24 \mathrm{mmol}, 43 \%$ ) with m.p. $111-113^{\circ} \mathrm{C}$ could be crystallized from ethanol. Recrystallization from ethanol gave m.p. $118-120^{\circ} \mathrm{C},[\alpha]_{\mathrm{D}}^{23}+60.1^{\circ}$ (c 2.9, chloroform). Anal. $\mathrm{C}_{25} \mathrm{H}_{35} \mathrm{BrO}_{16}$ : C, H. ${ }^{13} \mathrm{C}$ NMR $\left(\mathrm{CDCl}_{3}, 22.63 \mathrm{MHz}\right): 95.4$ (C-1), 70.1 (C-2), 69.2, 69.1 (C-3, C-4), 70.7 (C-5), 31.2 (C-6), $101.2\left(\mathrm{C}^{\prime} 1^{\prime}\right), \quad 72.3,72.1$ (C-2', $\left.\mathrm{C}-3^{\prime}\right), \quad 75.4$ (C-4'), $73.1\left(\mathrm{C}^{\prime} 5^{\prime}\right), 63.1\left(\mathrm{C}^{\prime} 6^{\prime}\right)$ and $57.0 \mathrm{ppm}$. (OMe).

Methyl 2,3,6,2',3',4'-hexa-O-acetyl-6'-deoxy- $\beta$ maltoside (2b). To a solution of the above 6 '-bromide $(600 \mathrm{mg}, 0.89 \mathrm{mmol})$ in ethyl acetate $(50 \mathrm{ml})$ was added triethylamine $(0.1 \mathrm{ml})$ and Raney nickel $(1 \mathrm{~g})$. The mixture was shaken under 2.5 atm hydrogen pressure for $3 \mathrm{~d}$. The catalyst was filtered off and washed with ethyl acetate, and the filtrate and washings were combined and evaporated to dryness. The residue was dissolved in dichloromethane $(50 \mathrm{ml})$, and the organic phase was washed three times with water $(25 \mathrm{ml})$. Drying over magnesium sulfate and evaporation to dryness gave a syrup $(520 \mathrm{mg})$, from which $2 \mathrm{~b}$ (400 $\mathrm{mg}, 0.68 \mathrm{mmol}$, $76 \%$ ) with m.p. $164-172^{\circ} \mathrm{C}$ was obtained. Recrystallization from ethanol gave $2 \mathrm{~b}$ with m.p. 173-175 ${ }^{\circ} \mathrm{C},[\alpha]_{\mathrm{D}}^{23}+49.5^{\circ}$ (c 1.1, chloroform). Lit. ${ }^{9}$ m.p. ${ }^{176-177}{ }^{\circ} \mathrm{C} .{ }^{13} \mathrm{C} \mathrm{NMR}\left(\mathrm{CDCl}_{3}, 22.63\right.$ MHz): 95.4 (C-1), 70.4 (C-2), 69.4 (C-3), 77.3 (C-4), 66.4 (C-5), 17.3 (C-6), 101.2 (C-1') 72.1, $72.2\left(\mathrm{C}-2^{\prime}, \mathrm{C}-3^{\prime}\right), 75.7\left(\mathrm{C}-4^{\prime}\right), 73.4\left(\mathrm{C}-5^{\prime}\right), 62.7$ $\left(\mathrm{C}-6^{\prime}\right)$ and $57.0 \mathrm{ppm}$. (OMe).

Methyl 6'-Deoxy- $\beta$-maltoside (2a). De-O-acetylation of $2 \mathrm{~b}(100 \mathrm{mg}, 0.17 \mathrm{mmol})$ in $0.1 \%$ sodium methoxide in methanol $(10 \mathrm{ml})$ yielded $2 \mathrm{a}$ (49 $\mathrm{mg}, 0.14 \mathrm{mmol}, 85 \%$ ) ) as a syrup. NMR data are given in Tables 1 and 2 .

Methyl 2,6-di-O-acetyl-4-O-(2,3,4,6-tetra-O-
acetyl- $\alpha$-D-glucopyranosyl)-3-deoxy- $\beta$ - $D$-ribo-
hexopyranoside (5b). Methyl 2,6-di- $O$-acetyl-
4- $O$ - $(2,3,4,6$-tetra- $O$-acetyl- $\alpha$-D-glucopyranos-
yl)-3-chloro-3-deoxy- $\beta$-D-allopyranoside ${ }^{11}$ (700 mg, $1.12 \mathrm{mmol}$ ) was dissolved in toluene. $\alpha, \alpha^{\prime}$-Azobisisobutyronitrile $(50 \mathrm{mg}, 0.33 \mathrm{mmol}$ ) and tributyltin hydride $(2 \mathrm{~g}, 3.1 \mathrm{mmol})$ were added, and the mixture was heated under reflux under nitrogen for $3 \mathrm{~h}$. After evaporation the product was purified by preparative TLC using ether as eluent (4 plates), yielding a syrup from which 4 (495 mg, $0.84 \mathrm{mmol}, 75 \%$ ) could be crystallized from ethanol. M.p. $85-90^{\circ} \mathrm{C}$. Recrystallization from ethanol gave 5b with m.p. $102-104^{\circ} \mathrm{C},[\alpha]_{D}^{23}$ $+56.3^{\circ}$ (c 0.6, chloroform). Anal. $\mathrm{C}_{25} \mathrm{H}_{36} \mathrm{O}_{16}$ : C, $\mathrm{H}$.

Methyl 3-deoxy-4-O-( $\alpha$-D-glucopyranosyl)- $\beta$ - $D$ ribo-hexopyranoside (5a). De-O-acetylation of $5 b(100 \mathrm{mg}, 0.17 \mathrm{mmol})$ in $0.1 \%$ sodium methoxide in methanol $(10 \mathrm{ml})$ yielded $5 \mathrm{a}(42 \mathrm{mg}, 0.12$ $\mathrm{mmol}, 73 \%$ ) as a syrup. NMR data are given in Tables 1 and 2 .

Methyl 4-O-(3,4,6-tri-O-acetyl-2-deoxy-2-iodo$\alpha$-D-mannopyranosyl)-2,3-6-tri-O-benzyl- $\beta$ - $D$ - 
glucopyranoside (8). A mixture of 3,4,6-tri- $O$-acetyl-1,5-anhydro-2-deoxy-D-arabino-hex-1-enitol $(7)^{20}(250 \mathrm{mg}, 0.92 \mathrm{mmol})$, methyl 2,3,6-tri- $O$-benzyl- $\beta$-D-glucopyranoside $(6)^{12}(200$ $\mathrm{mg}, 0.43 \mathrm{mmol}$ ), $N$-iodosuccinimide ${ }^{21}$ (35: $\mathrm{mg}$, $1.56 \mathrm{mmol})$ and $3 \AA$ molecular sieves in acetonitrile $(2 \mathrm{ml})$ was stirred in the dark under nitrogen for $3 \mathrm{~d}$. The reaction mixture was diluted with dichloromethane $(20 \mathrm{ml})$, filtered and washed three times with $4 \mathrm{M}$ hydrochloric acid and three times with saturated sodium hydrogen carbonate solution. Drying over magnesium sulfate and evaporation to dryness yielded a syrup $(433 \mathrm{mg})$, which was applied to a column of silica gel. Elution with ethyl acetate/light petroleum (1:3) yielded 8 as a syrup $(95 \mathrm{mg}, 0.11 \mathrm{mmol}$, $26 \%) .{ }^{13} \mathrm{C} \mathrm{NMR}\left(\mathrm{CDCl}_{3}, 22.3 \mathrm{MHz}\right): 104.6(\mathrm{C}-1$, $\left.J_{\mathrm{C}-1, \mathrm{H}-1} 154 \mathrm{~Hz}\right), 102.9\left(\mathrm{C}-1^{\prime}, J_{\mathrm{C}-1^{\prime}, \mathrm{H}-1} 180 \mathrm{~Hz}\right), 57.1$ (O-methyl) and $29.7 \mathrm{ppm}\left(\mathrm{C}-2^{\prime}\right)$. Other signals: 83.8, 82.3, 77.5, 75.1, 74.4, 74.3, 73.6, 70.0, 69.4, $68.7,67.7$ and $62.2 \mathrm{ppm}$. From the crude product, unreacted $6(54 \mathrm{mg}, 0.12 \mathrm{mmol})$ could be isolated.

Methyl 2,3,6-tri-O-acetyl-4-O-(3,4,6-tri-O-acetyl-2-deoxy- $\alpha$ - $D$-arabino-hexopyranosyl)- $\beta$ - $D$-glucopyranoside (9b). To a solution of $8(95 \mathrm{mg}, 0.11$ $\mathrm{mmol})$ in toluene $(5 \mathrm{ml})$ was added tributyltin hydride $^{22}$ (100 $\left.\mathrm{mg}, 0.34 \mathrm{mmol}\right)$ and the mixture was stirred under nitrogen for $2 \mathrm{~h}$. Evaporation left a syrup which was purified by chromatography on a column packed with silica gel using ethyl acetate/light petroleum (1:3) as eluent. The syrupy product $(63 \mathrm{mg})$ was dissolved in methanol $(20 \mathrm{ml})$ and acetic acid $(4 \mathrm{ml})$, and $5 \%$ palladium on activated carbon $(20 \mathrm{mg}$ ) was added. The mixture was stirred under 1 atm hydrogen pressure for $16 \mathrm{~h}$. The catalyst was filtered off, washed with methanol, and the combined organic phases were evaporated to dryness, yielding a syrup $(35 \mathrm{mg})$ which was treated with acetic anhydride $(5 \mathrm{ml})$ and pyridine $(5 \mathrm{ml})$ for $16 \mathrm{~h}$. Work-up by evaporation and chromatography on a column of silica gel with ethyl acetate/light petroleum (1:1) as eluent yielded $9 \mathrm{~b}$ as a syrup (40 $\mathrm{mg}, 0.068 \mathrm{mmol}, 62 \%$ ). Crystallization from ethanol gave 9b with m.p. $168-169^{\circ} \mathrm{C},[\alpha]_{\mathrm{D}}^{23}+37.6^{\circ}$ (c 1.8, chloroform). Anal. $\mathrm{C}_{25} \mathrm{H}_{36} \mathrm{O}_{16}: \mathrm{C}, \mathrm{H}$.

Methyl 4-O-(2-deoxy- $\alpha-D$-arabino-hexopyranosyl)- $\beta$-D-glucopyranoside (9a). De- $O$-acetylation of $9 \mathrm{~b}(30 \mathrm{mg}, 0.05 \mathrm{mmol})$ in $0.1 \%$ sodium meth- oxide in methanol $(5 \mathrm{ml})$ yielded $9 \mathrm{a}(13 \mathrm{mg}, 0.04$ mmol, $80 \%$ ) as a syrup. NMR data are given in Tables 1 and 2.

\section{2,4,6-Tri-O-benzyl-3-deoxy- $\alpha$ - $D$-ribo-hexopyra-} nosyl chloride (10). A solution of methyl 4,6-Obenzylidene-3-deoxy- $\alpha$-D-ribo-hexopyranoside ${ }^{14}$ $(1.0 \mathrm{~g}, 3.76 \mathrm{mmol})$ in acetic acid $(40 \mathrm{ml})$ and water $(10 \mathrm{ml})$ was heated on a steam bath for 30 min. The mixture was evaporated to dryness, water $(10 \mathrm{ml})$ was added and evaporated three times, and the residue was dissolved in $\mathrm{N}, \mathrm{N}$-dimethylformamide $(15 \mathrm{ml})$. A slurry of sodium hydride $(0.5 \mathrm{~g}, 20 \mathrm{mmol})$ in $N, N$-dimethylformamide $(10 \mathrm{ml})$ was added and the mixture was stirred for $1 \mathrm{~h}$. Benzyl bromide $(1.8 \mathrm{ml}, 15 \mathrm{mmol})$ was added and the mixture was stirred for $16 \mathrm{~h}$. Methanol $(10 \mathrm{ml})$ was added in small portions with cooling, and the mixture was stirred for 30 $\mathrm{min}$. The mixture was then poured into water (50 $\mathrm{ml}$ ) and the $\mathrm{pH}$ was adjusted to 7 with acetic acid. The mixture was extracted three times with dichloromethane, and the combined organic phases were washed three times with $4 \mathrm{~m}$ hydrochloric acid and three times with saturated sodium hydrogen carbonate solution. Drying over magnesium sulfate and evaporation yielded a syrup, which was applied to a column of silica gel. Elution with ethyl acetate/light petroleum (6:1) yielded the glycoside $(1.01 \mathrm{~g}, 2.26 \mathrm{mmol}, 60 \%)$. $[\alpha]_{\mathrm{D}}^{23}+63.5^{\circ}$ (c 1.8, chloroform). ${ }^{13} \mathrm{C}$ NMR $\left(\mathrm{CDCl}_{3}, 22.63 \mathrm{MHz}\right): 97.2(\mathrm{C}-1), 54.7(O-$ methyl) and $30.1 \mathrm{ppm}(\mathrm{C}-3)$. Other signals at $73.7,73.5,71.9,71.1,70.8,70.6$ and $68.8 \mathrm{ppm}$.

The benzylated glycoside $(400 \mathrm{mg}, 0.89 \mathrm{mmol})$ was dissolved in ether $(50 \mathrm{ml})$ saturated with hydrogen chloride at $0^{\circ} \mathrm{C}$. The solution was evaporated at room temperature, and toluene $(10 \mathrm{ml})$ was added and evaporated twice. The resulting syrupy 10 (405 mg, $0.89 \mathrm{mmol}, 100 \%$ ) was used immediately. The $90 \mathrm{MHz}{ }^{1} \mathrm{H}$ NMR spectrum showed a doublet $(J 3.3 \mathrm{~Hz})$ at $6.1 \mathrm{ppm}$, typical for $\mathrm{H}-1$ in a glycosyl chloride.

Methyl 2,3,6-tri-O-benzyl-4-O-(2,4,6-tri-O-benzyl-3-deoxy- $\alpha$ - $D$-ribo-hexopyranosyl)- $\beta$ - $D$-glucopyranoside (11c) and methyl 2,3,6-tri-O-benzyl-4-O-(2,4,6-tri-O-benzyl-3-deoxy- $\beta$ - $D$-ribohexopyranosyl)- $\beta$-D-glycopyranoside. To a mixture of $6(180 \mathrm{mg}, \quad 0.39 \mathrm{mmol})$, silver trifluoromethanesulfonate $(50 \mathrm{mg}, 0.97 \mathrm{mmol})$ and $4 \AA$ molecular sieves cooled to $-70^{\circ} \mathrm{C}$ was 
added a solution of $10(405 \mathrm{mg}, 0.89 \mathrm{mmol})$ in toluene $(2 \mathrm{ml})$, nitromethane $(2 \mathrm{ml})$ and tetramethylurea $(0.2 \mathrm{ml})$. The mixture was stirred under nitrogen at $-23^{\circ} \mathrm{C}$ for $16 \mathrm{~h}$, and was then allowed to reach room temperature. The mixture was diluted with dichloromethane $(25 \mathrm{ml})$ and filtered through celite. The organic phase was washed three times with $4 \mathrm{M}$ hydrochloric acid $(10 \mathrm{ml})$ and three times with saturated sodium hydrogen carbonate solution $(10 \mathrm{ml})$. Drying over magnesium sulfate and evaporation to dryness yielded a syrup $(420 \mathrm{mg})$, which was purified by preparative TLC ( 2 plates) by elution with ethyl acetate/light petroleum (1:3). The slower moving fraction gave $11 \mathrm{c}(132 \mathrm{mg}, 0.15 \mathrm{mmol}$, $38 \%$, for which the $90 \mathrm{MHz}{ }^{1} \mathrm{H}$ NMR spectrum showed a doublet $(J 3.8 \mathrm{~Hz})$ at $5.6 \mathrm{ppm}(\alpha \mathrm{H}-1)$. The faster moving fraction yielded material (130 $\mathrm{mg}, 0.16 \mathrm{mmol}, 38 \%$ ) which on catalytic hydrogenation gave a product for which the $90 \mathrm{MHz}^{1} \mathrm{H}$ NMR spectrum in deuterium oxide showed two doublets $(J 7.5 \mathrm{~Hz})$ at about $4.4 \mathrm{ppm}(\beta \mathrm{H}-1$ and $\left.\beta \mathrm{H}-1^{\prime}\right)$.

Methyl 4-O-(3-deoxy- $\alpha$-D-ribo-hexopyranosyl)$\beta$-D-glucopyranoside (11a). To a solution of 11c $(132 \mathrm{mg}, 0.15 \mathrm{mmol})$ in methanol $(20 \mathrm{ml})$ and acetic acid $(5 \mathrm{ml})$ was added $5 \%$ palladium on activated carbon $(30 \mathrm{mg})$. The mixture was stirred for $16 \mathrm{~h}$ under $1 \mathrm{~atm}$ hydrogen pressure. The catalyst was filtered off and washed with methanol. The filtrate and washings were combined and evaporated. Water $(5 \mathrm{ml})$ was added and evaporated twice to remove traces of acetic acid. This procedure left $11 \mathrm{a}(45 \mathrm{mg}, 0.13 \mathrm{mmol}$, $88 \%$ ). NMR data are given in Tables 1 and 2.

\section{Methyl 2,3,6-tri-O-acetyl-4-O-(2,4,6-tri-O-ace-} tyl-3-deoxy- $\alpha$-D-ribo-hexopyranosyl)- $\beta$-D-gluco-

pyranoside (11b). Compound 11a $(20 \mathrm{mg}, 0.059$ mmol) was treated with pyridine $(2 \mathrm{ml})$ and acetic anhydride $(2 \mathrm{ml})$ for $16 \mathrm{~h}$. The reaction mixture was concentrated, and toluene $(10 \mathrm{ml})$ was added and evaporated twice. The resulting syrup was applied to a column of silica gel and eluted with ethyl acetate/light petroleum (1:1), yielding 11b as a syrup $(30 \mathrm{mg}, 0.051 \mathrm{mmol})$ with $[\alpha]_{\mathrm{D}}^{23}+51.2^{\circ}$ (c 0.4, chloroform). Anal. $\mathrm{C}_{25} \mathrm{H}_{36} \mathrm{O}_{16}: \mathrm{C}, \mathrm{H}$.

Methyl 2,3,6,2',3'-penta-O-benzyl-4',6'-O-benzylidene- $\beta$-maltoside (12). To a solution of methyl $4^{\prime}, 6^{\prime}$ - $O$-benzylidene $-\beta$-maltoside ${ }^{19}(680 \mathrm{mg}, 1.53$ mmol) in $N, N$-dimethylformamide $(10 \mathrm{ml})$ was added a slurry of sodium hydride $(350 \mathrm{mg}, 14.6$ mmol) in $N, N$-dimethylformamide $(10 \mathrm{ml})$. The mixture was stirred for $1 \mathrm{~h}$, and benzyl bromide $(1.0 \mathrm{ml}, 8.4 \mathrm{mmol})$ was added and the mixture was stirred for $16 \mathrm{~h}$. Methanol $(10 \mathrm{ml})$ was added in portions with cooling. The mixture was stirred for $30 \mathrm{~min}$ and then poured into water $(50 \mathrm{ml})$, and the $\mathrm{pH}$ was adjusted to 7 with acetic acid. The mixture was extracted three times with dichloromethane $(25 \mathrm{ml})$, and the combined organic phases were washed three times with $4 \mathrm{M}$ hydrochloric acid and three times with saturated hydrogen carbonate solution. Drying and evaporation of the organic phase yielded a syrup, which was applied to a column of silica gel. Elution with ethyl acetate/light petroleum (1:4) yielded 12 as a syrup $(983 \mathrm{mg}, 1.10 \mathrm{mmol}, 72 \%$ ) with $[\alpha]_{D}^{23}+17.7^{\circ}$ (c 1.9, chloroform). Anal. $\mathrm{C}_{55} \mathrm{H}_{58} \mathrm{O}_{11}: \mathrm{C}, \mathrm{H} .{ }^{13} \mathrm{C} \mathrm{NMR}\left(\mathrm{CDCl}_{3}, 22.63 \mathrm{MHz}\right)$ : 104.4 (C-1) 101.0 (benzylidenic), 97.1 (C-1') and $56.8 \mathrm{ppm}$ (O-methyl). Other signals at 84.7, 82.0 ( 2 carbons), 78.6 ( 2 carbons), 75.1 74.4, 74.2, $73.6,73.3,72,0$ ( 2 carbons), 68.8 ( 2 carbons) and $63.2 \mathrm{ppm}$.

Methyl 2,3,6,2',3',6'-hexa-O-benzyl- $\beta$-maltoside (13a). To a solution of $12(900 \mathrm{mg}, 1.0 \mathrm{mmol})$ and sodium cyanoborohydride $(800 \mathrm{mg}, 12 \mathrm{mmol})$ in tetrahydrofuran $(30 \mathrm{ml}$, freshly distilled from lithium aluminium hydride) was added ether saturated with hydrogen chloride until the evolution of gas had ceased. After 5 min the mixture was diluted with dichloromethane $(50 \mathrm{ml})$, and washed twice with water $(20 \mathrm{ml})$ and three times with saturated sodium hydrogen carbonate solution $(20 \mathrm{ml})$. Drying over magnesium sulfate and evaporation of the organic phase yielded a syrup, which was applied to a column of silica gel. Elution with ethyl acetate/light petroleum (1:4) yielded 13a as a syrup (566 $\mathrm{mg}, 0.63 \mathrm{mmol}, 63 \%$ ) with $[\alpha]_{\mathrm{D}}^{23}+23.0^{\circ}$ (c 0.7, chloroform). Anal. $\mathrm{C}_{55} \mathrm{H}_{60} \mathrm{O}_{11}: \mathrm{C}, \mathrm{H} .{ }^{13} \mathrm{C} \mathrm{NMR}\left(\mathrm{CDCl}_{3}, 22.63 \mathrm{MHz}\right)$ : $104.6(\mathrm{C}-1), 96.6\left(\mathrm{C}-1^{\prime}\right)$ and $56.9 \mathrm{ppm}(O-$ methyl). Other signals at $84.8,82.3,81.3,78.9$, 75.3, 74.6 ( 2 carbons), 73.8, 73.6, 73.3, 73.0, $72.6,71.4,70.7,69.7$ and $69.1 \mathrm{ppm}$.

Methyl 2,3,6,2',3',6'-hexa-O-benzyl-4'-O-phenoxythiocarbonyl- $\beta$-maltoside (13d). To a so- 
lution of $13 \mathrm{a}(856 \mathrm{mg}, 0.90 \mathrm{mmol})$ in dichloromethane $(30 \mathrm{ml})$ and pyridine $(5 \mathrm{ml})$ was added phenoxythiocarbonyl chloride ${ }^{23}(200 \mathrm{mg}, 1.16$ $\mathrm{mmol})$. The mixture was stirred for $16 \mathrm{~h}$ and then ice $(5 \mathrm{ml})$ was added. After stirring for $1 \mathrm{~h}$, the mixture was washed three times with $4 \mathrm{M}$ hydrochloric acid $(15 \mathrm{ml})$ and three times with saturated sodium hydrogen carbonate solution. Drying over magnesium sulfate and evaporation of the organic phase yielded a syrup $(1.02 \mathrm{~g})$, which was purified by preparative TLC (4 plates) with ethyl acetate/light petroleum (1:3) as eluent. Yield of 13d, $296 \mathrm{mg}(0.261 \mathrm{mmol}, 30 \%)$. The 90 $\mathrm{MHz}{ }^{1} \mathrm{H}$ NMR spectrum showed a triplet ( $J 9.7$ $\mathrm{Hz})$ at $5.65 \mathrm{ppm}\left(\mathrm{H}-4^{\prime}\right) .{ }^{13} \mathrm{C} \mathrm{NMR}\left(\mathrm{CDCl}_{3}, 22.63\right.$ $\mathrm{MHz})$ : 104.7 (C-1), $96.6\left(\mathrm{C}-1^{\prime}\right)$ and $57.0 \mathrm{ppm}$ $(O$-methyl). Other signals at $84.7,82.4,80.7$, $79.5,79.0,75.5,74.6,74.0,73.8,73.7,73.6,73.4$, $69.4,69.3$ and $68.9 \mathrm{ppm}$.

Methyl 2,3,6-tri-O-benzyl-4-O-(2,3,6-tri-O-benz$y$ l-4-deoxy- $\alpha$ - $D$-xylo-hexopyranosyl)- $\beta$ - $D$-glucopyranoside (14c). To a solution of $13 \mathrm{~d}(250 \mathrm{mg}$, $0.24 \mathrm{mmol}$ ) in toluene was added tributyltin hy$\operatorname{dride}^{22}(200 \mathrm{mg}, 0.69 \mathrm{mmol})$ and $\alpha, \alpha^{\prime}$ azobisisobutyronitrile $(10 \mathrm{mg}, 0.06 \mathrm{mmol})$. The mixture was heated under reflux under nitrogen for $1 \mathrm{~h}$, and was then left for $16 \mathrm{~h}$ at room temperature under nitrogen. The reaction mixture was evaporated, leaving a syrup which was purified by preparative TLC ( 2 plates) with dichloromethane/methanol (95:5) as eluent. This yielded $14 \boldsymbol{c}$ as a syrup (141 $\mathrm{mg}, 0.16 \mathrm{mmol}, 67 \%)$ with $[\alpha]_{\mathrm{D}}^{23}+30.4^{\circ}(c 0.9$ chloroform). Anal. $\mathrm{C}_{55} \mathrm{H}_{60} \mathrm{O}_{10}: \mathrm{C}, \mathrm{H} .{ }^{13} \mathrm{C}$ NMR $\left(\mathrm{CDCl}_{3}, 22.63 \mathrm{MHz}\right)$ : 104.5 (c-1), $97.6\left(\mathrm{C}-1^{\prime}\right)$, $57.0\left(O\right.$-methyl) and $33.8 \mathrm{ppm}\left(\mathrm{C}-4^{\prime}\right)$. Other signals at $84.8,82.4,80.0,75.5,74.6$ (2 carbons), $73.9,73.4$ ( 2 carbons), 72.8 (2 carbons), 72.3, $72.0,69.7$ and $67.6 \mathrm{ppm}$.

Methyl 4-O-(4-deoxy- $\alpha$-D-xylo-hexopyranosyl)$\beta$-D-glucopyranoside (14a). To a solution of $14 \mathrm{c}$ $(140 \mathrm{mg}, 0.16 \mathrm{mmol})$ in methanol $(10 \mathrm{ml})$ and acetic acid $(2 \mathrm{ml})$ was added $5 \%$ palladium on activated carbon $(50 \mathrm{mg})$. The mixture was stirred under $1 \mathrm{~atm}$ hydrogen pressure for $16 \mathrm{~h}$. The catalyst was filtered off and washed with methanol, and the combined filtrate and washings were evaporated. Water $(5 \mathrm{ml})$ was added and evaporated three times to remove traces of acetic acid. This yielded 14a as a syrup $(50 \mathrm{mg}$,
$0.15 \mathrm{mmol}, 95 \%$ ). NMR data are given in Tables 1 and 2 .

Methyl 2,3,2', $4^{\prime}$-penta-O-acetyl-6,6'-dideoxy$6,6^{\prime}$-diodo- $\beta$-maltoside. Methyl $\beta$-maltoside monohydrate $(2,6 \mathrm{~g}, 6.96 \mathrm{mmol})$ was dried at 20 $\mathrm{mmHg}$ and $120^{\circ} \mathrm{C}$ for $20 \mathrm{~h}$. It was then dissolved in pyridine $(25 \mathrm{ml})$ and the solution was cooled to $0^{\circ} \mathrm{C}$. A cold solution of methanesulfonyl chloride $(1.05 \mathrm{ml}, 14.0 \mathrm{mmol})$ in pyridine $(20 \mathrm{ml})$ was added, and the mixture was left at $0^{\circ} \mathrm{C}$ for $16 \mathrm{~h}$. Acetic anhydride $(10 \mathrm{ml})$ was added, and the mixture was left at room temperature for $24 \mathrm{~h}$. Conventional work-up gave the dimesylate as a syrup (4.96 g), which was crystallized and recrystallized from ethanol to give methyl $2,3,2^{\prime}, 3^{\prime}, 4^{\prime}$-penta- $O$-acetyl-6, $6^{\prime}$-di- $O$-mesyl- $\beta$ -

maltoside (1.74 g, $2.41 \mathrm{mmol}, 35 \%)$ with m.p. $163-171^{\circ} \mathrm{C}$. Further recrystallizations from ethanol gave m.p. $170-172^{\circ} \mathrm{C},[\alpha]_{\mathrm{D}}^{23}+60.3^{\circ}$ (c 0.6, chloroform). Lit. ${ }^{24}$ m.p. $175-176^{\circ} \mathrm{C},[\alpha]_{D}^{23}+56.5^{\circ}$ (c 1.5, chloroform).

A solution of the mesylate $(1.0 \mathrm{~g}, 1.39 \mathrm{mmol})$ in $N, N$-dimethylformamide $(10 \mathrm{ml})$ was treated with sodium iodide $(1.0 \mathrm{~g}, 6,7 \mathrm{mmol})$ at $100^{\circ} \mathrm{C}$ for $16 \mathrm{~h}$. TLC (ether) showed no starting material but several new compounds. Water $(25 \mathrm{ml})$ and dichloromethane $(50 \mathrm{ml})$ were added, and the phases were separated. The aqueous phase was extracted with dichloromethane $(25 \mathrm{ml})$, and the combined organic phases were washed twice with $10 \%$ sodium thiosulfate solution $(25 \mathrm{ml})$ and three times with water. Drying over magnesium sulfate and evaporation of the organic phase left a syrup $(1.02 \mathrm{~g})$. This was treated with acetic anhydride $(20 \mathrm{ml})$ and pyridine $(20 \mathrm{ml})$ for $16 \mathrm{~h}$. Conventional work-up gave a syrup $(1.03 \mathrm{~g})$, from which the title compound $(830 \mathrm{mg}, 1.06$ mmol, $76 \%$ ) with m.p. $175-181{ }^{\circ} \mathrm{C}$ could be crystallized from ethanol. Recrystallization from ethanol gave m.p. $196-197^{\circ} \mathrm{C},[\alpha]_{\mathrm{D}}^{24}+50.3^{\circ}(c 2.3$, chloroform). Lit. $^{9}$ m.p. $196-197^{\circ} \mathrm{C},[\alpha]_{\mathrm{D}}^{24}+48.2^{\circ}$ (c 7.6, chloroform).

Methyl 2,3,2',3',4'-Penta-O-acetyl-6,6'-dideoxy$\beta$-maltoside (15b). To a solution of the diiodide (278 $\mathrm{mg}, 0.35 \mathrm{mmol})$ in ethyl acetate was added triethylamine $(0.1 \mathrm{ml})$ and Raney nickel $(1 \mathrm{~g})$, and the mixture was shaken under 2.5 atm hydrogen pressure for $16 \mathrm{~h}$. The catalyst was filtered off and washed well with ethyl acetate. The com- 
bined filtrate and washings were evaporated to dryness. The residue was dissolved in dichloromethane $(50 \mathrm{ml})$, and the organic phase was washed three times with water $(25 \mathrm{ml})$. Drying over magnesium sulfate and evaporation of the organic phase gave a syrup $(180 \mathrm{mg})$, from which $15 \mathrm{~b}(130 \mathrm{mg}, 0.25 \mathrm{mmol}, 70 \%)$ with m.p. 157$159^{\circ} \mathrm{C}$ could be crystallized from ethanol. Recrystallization from ethanol gave $15 \mathrm{~b}$ with m.p. $160-162^{\circ} \mathrm{C},[\alpha]_{\mathrm{D}}^{23}+53.1^{\circ}$ (c 0.3 , chloroform). Lit. ${ }^{y}$ m.p. $186-187^{\circ} \mathrm{C},[\alpha]_{\mathrm{D}}^{24}+50.0^{\circ}(c 3.0$, chloroform).

Methyl 6,6'-dideoxy- $\beta$-maltoside (15a). De-Oacetylation of $15 \mathrm{~b}(100 \mathrm{mg}, 0.19 \mathrm{mmol})$ with $0.1 \%$ sodium methoxide in methanol $(10 \mathrm{ml})$ yielded $15 \mathrm{a}(46 \mathrm{mg}, 0.14 \mathrm{mmol}, 75 \%$ ) as a syrup. NMR data are given in Tables 1 and 2 .

1,5-Anhydro-2-deoxy-4-O-( $\alpha$-D-glucopyranosyl)$D$-arabino-hexitol (16a). Hexa- $O$-acetylmaltal ${ }^{20}$ $(1.0 \mathrm{~g}, 1.8 \mathrm{mmol})$ was dissolved in ethyl acetate $(10 \mathrm{ml})$, and $\mathrm{Pd} / \mathrm{C}(5 \%, 120 \mathrm{mg})$ was added and the reaction mixture hydrogenated at $1 \mathrm{~atm}$ hydrogen pressure for $24 \mathrm{~h}$. Filtration and evaporation followed by crystallization from ether gave 16b (935 mg, $93 \%)$, m.p. $107-115^{\circ} \mathrm{C}$. Recrystallization from the same solvent gave $\mathbf{1 6 b}$ with m.p. $117-120^{\circ} \mathrm{C},[\alpha]_{\mathrm{D}}^{23}+84.3^{\circ}$ (c 1.4 , $\left.\mathrm{CHCl}_{3}\right)$. Deacetylation of $16 \mathrm{~b}(545 \mathrm{mg}, 97 \mathrm{mmol})$ with methanolic sodium methoxide $(2 \mathrm{ml}, 1)$ in methanol $(10 \mathrm{ml})$ gave the unprotected compound 16a as a syrup in $93 \%$ yield after removal of the sodium ions with ion exchange resin (IR $\left.120, \mathrm{H}^{+}\right)$. NMR data are given in Tables 1 and 2.

Qualitative degradation experiments. General procedure. The substrate ( $2 \mathrm{mg}$ ) was dissolved in $0.1 \mathrm{M}$ acetate buffer $(0.5 \mathrm{ml}, \mathrm{pH} 4.3)$. AMG solution $\left(10 \mu \mathrm{l}, 3.9 \times 10^{-8} \mathrm{M}\right)$ was added, and the mixture was heated to $50^{\circ} \mathrm{C}$ on a water bath for $1 \mathrm{~h}$. The reaction mixture was analyzed by TLC using ethyl acetate/methanol/acetic acid/water $(6: 2: 1: 1)$ as eluent. Relevant reference compounds were used. Negative results were confirmed by addition of more enzyme and increasing the incubation times. When the results from the TLC analyses were not clear, the reaction mixtures were evaporated and analyzed by ${ }^{1} \mathrm{H}$ NMR spectroscopy.
Dynamic degradation experiments. General procedure. The substrates (1-10 mg) were dissolved in acetate buffer $(0.7 \mathrm{ml}, 0.1 \mathrm{M}$. pH 4.3$)$ prepared from anhydrous sodium acetate, acetic acid and deuterium oxide. Nitrogen was bubbled through the sample, and it was thermostatted to the desired temperature $\left(27\right.$ or $\left.37^{\circ} \mathrm{C}\right)$. AMG solution $\left(10 \mu \mathrm{l}, 3.9 \times 10^{-8} \mathrm{M}\right)$ in the deuterium buffer was added, and the sample was transferred to a $5 \mathrm{~mm}$ NMR tube and ${ }^{1} \mathrm{H}$ NMR spectra $(500$ $\mathrm{MHz}$ ) were recorded at suitable time intervals.

Acknowledgements. This work has been supported by a grant from the Danish Technical Research Council and Novo A/S to H.P., and from a Nato travel grant (RG 85.0021) to K.B. The 500 $\mathrm{MHz}$ NMR spectrometer was provided by the Danish Natural Science Research Council and The Carlsberg Foundation. The authors wish to thank Mr. T. Pedersen and Mr. J. J. Hansen for their contributions during the early stages of this project.

\section{References}

1. Hindsgaul, O., Khare, D. P., Bach, M. and Lemieux, R. U. Can. J. Chem. 63 (1985) 2653.

2. Spohr, U., Morishima, N., Hindsgaul, O. and Lemieux, R. U. Can. J. Chem. 63 (1985) 2659.

3. Lemieux, R. U., Venot, A. P., Spohr, U., Bird, P., Mandal, F., Morishima, N., Hindsgaul, O. and Bundle, D. R. Can. J. Chem. 63 (1985) 2664.

4. Lemieux, R. U. The Hydrated Polar-Group Gate Effect on the Specificity and Strength of the Binding of Oligosaccharides by Protein Receptor Sites. In: Proceedings of the VII. International Symposium on Medicinal Chemistry, Uppsala, Sweden, August 27-31, 1984, p. 329.

5. Bock, K. Pure Appl. Chem. In press.

6. Bock, K. and Pedersen, H. Protein-Carbohydrate Interactions: The Substrate Specificity of Amyloglycosidase (EC 3.2.1.3). In: Lark, D., Ed., Molecular Biology of Microbial Pathogenicity, Academic Press, London 1986, p. 173.

7. Svensson, B., Larsen, K., Svendsen, I. and Boel, E. Carlsberg Res. Commun. 48 (1983) 529.

8. Takeo, K. Carbohydr. Res. 69 (1979) 272.

9. Sleeter, R. T. and Sinclair, H. B. J. Org. Chem. 35 (1970) 3804 . 
10. Mori, M., Haga, M. and Tejima, S. Chem. Pharm. Bull. 22 (1974) 1331.

11. Durette, P. L., Hough, L. and Richardson, A. C. J. Chem. Soc., Perkin Trans. 1 (1974) 88.

12. Garegg, P. J., Hultberg, H. and Wallin, S. Carbohydr. Res. 108 (1982) 97.

13. Thiem, J., Karl, H. and Schwentner, J. Synthesis (1978) 696.

14. Vis, E. and Karrer, P. Helv. Chim. Acta. 37 (1954) 378.

15. Lemieux, R. U., Hendriks, K. B., Stick, R. V. and James, K. J. Am. Chem. Soc. 97 (1975) 4056.

16. Robins, M. J., Wilson, J. S. and Hansske, F. J. Am. Chem. Soc. 105 (1983) 4059.

17. Lemieux, R. U. and Alvaredo, E. Private communication.

18. Bock, K. and Sigurskjold, B.W. Biochem. J. (1987). To be submitted.
19. Aspinall, G. O., Krishnamurthy, T. N., Mitura, W. and Funabashi, M. Can. J. Chem. 53 (1975) 2182.

20. Haworth, W. N., Hirst, E. L. and Reynolds, R. J. W. J. Chem. Soc. (1934) 302.

21. Benson, W. R., McBee, E. T. and Rand, L. Org. Synth. 42 (1962) 73.

22. Hayashi, K., Iyoda, J. and Shiihara, I. J. Organomet. Chem. 10 (1967) 81.

23. Miyazaki, M. and Nakanishi, K. Jpn. Tokyo Koho (1957) 1322; Chem. Abstr. 52 (1958) 4684.

24. Newth, F. H., Nicholas, S. D., Smith, F. and Wiggings, L. F. J. Chem. Soc. (1949) 2550.

Received May 27, 1987. 